\title{
The Views of Teacher Candidates Attending the Pedagogical Formation Program Regarding the Teaching Practice Course*
}

\author{
Fevzi Dursun ** \\ Gaziosmanpasa University, TURKEY
}

\author{
Zafer Kiraz \\ Gaziosmanpasa University, TURKEY
}

Received: September15, $2017 \cdot$ Revised: September28, $2017 \cdot$ Accepted: October10, 2017

\begin{abstract}
One of the important aspects that increase the efficiency of learning is well trained teacher. Besides, increasing quality and ensuring permanent learning is undoubtedly dependent on teacher's effort to achieve these and active participation of student in the teaching process more actively and willingly. This study was conducted to review the views of teacher candidates for the practices they performed at relevant schools in the scope of teaching practice. In the study, it was aimed to determine what teachers have carried out for the teaching process to be more qualified. In the study, six open-ended questions were asked to 26 teacher candidates, working at central district of Tokat province during the spring semester of 2015-2016 academic year, received pedagogical formation, agreed voluntarily respond to the information on the form in pre-interview. The study conducted qualitatively. In the analysis of the data, descriptive analysis technique from qualitative data analysis techniques was used. According to findings, it is seen that participants experienced various problems during teaching practice. The participants found short haul and temporary solutions that they usually developed by themselves to overcome their problems that they experienced. The majority of the participants expressed that they benefited from teaching practice course in the topics of lecturing, addressing, recognizing students, communicating with students, classroom management and attracting attention. The majority of the participants stated that teaching practice satisfied their expectations from this practice. It was found that the participants didn't have enough knowledge about the practice itself, so their expectations from this practice was low. The fact that participants' expectations were low and they didn't have enough knowledge about the practice shows that the practice in question satisfied their expectations easier and faster. Regarding the participants' expectations about how teaching practice should be and what it should include; they expect for teaching staff and practice teacher to get more involved with participants and course; the lesson plans to be more planned and functional, the communication of instructors, and practice teachers at school to be better.
\end{abstract}

Keywords: Teaching practice, pedagogical formation education, teacher candidate.

To cite this article: Dursun, F., \& Kiraz, Z. (2017). The views of teacher candidates attending the pedagogical formation program regarding the teaching practice course. European Journal of Educational Research, 6(4), 510-521.doi: 10.12973/eu-jer.6.4.510

\section{Introduction}

The issue of teacher training, and improving the quality of teachers has been investigated and discussed in not only our country, but also in many countries. In this context, the studies have been conducted for the issue of teacher training in Turkey, and arising problems have been tried to be solved (Oguz, 2004). It was discussed how to train a qualified teacher aiming to raise the quality of pre-service teacher education in the framework of the Higher Education Council / World Bank National Education Development Project, which was put into practice in Turkey in 1994, ,as a result of these discussions, it has been decided that the teaching formation couldn't gain sufficiently to teacher candidates in the education faculties. In other words, it was determined that the candidate teachers were sufficient in terms of field knowledge, but had rough edges in terms of knowledge, and skills for the implementation of teaching profession (Harmandar et al., 2000).Thus, with the collaborative work of the Higher Education Council (HEC) and the World Bank in 1998, new arrangements were made in teacher education; time that teacher candidates will spend in practice schools were increased, and the school experience and teaching practice courses for teaching profession practice have been included in teaching programs (HEC, 1998).Indeed, the most important dimension of the program in teacher training institutions is internship and application activities (Kucukahmet, 2007).

The content of education teacher candidates who receive education in education faculties in eighth semester, and that of "Teaching Practice" course that formation students receive in second semester includes preparation of a daily plan

\footnotetext{
* This study is the improved version of the oral declaration presented at the III. IDEAL Conference carried out in Samsun between 01-03 September 2016.

** Corresponding author:

Fevzi Dursun , Gaziosmanpasa University, Faculty of Education, Department of Education Science, 60240 Tokat, TURKEY

Email:fevzi.dursun@gop.edu.tr
} 
every week; application the prepared plan, evaluation of the application by the school teacher; teaching staff and application student; making arrangements in line with these evaluations, and preparation of portfolio (HEC, 2005)

Teaching practice courses have different hours and credits. For example, the courses lasts 12 weeks in Australia; $1 / 4$ of a school year (1 year) in Holland; for a semester in Belgium. Teaching practice courses provide teacher candidates with awareness of suitability for teaching profession, teaching experience, and give candidates opportunity to socialize. Also these courses have some effects, such as transforming teaching-learning theories into practice, shaping candidates' perceptions towards students, comprehending the responsibilities of teaching profession, and improving teaching skills (Saglam, 1999, La Master, 2001, Wagler, 2007 as cited in Becit, Kurt, Kabakci, 2009).

Teaching practice is crucial for teacher candidates starting to teaching. It is assumed that there are written regulations about process of the period and all instructors should generally follow these regulations.

Instructors, observing each candidate only once or twice usually and are important for educating teacher candidates, don't give appropriate instructions because of the reasons, such as course load of the practice teacher, the teachers' emotional approach, unsuitable plan, practice teachers without pedagogical formation, giving less attention to practice; hence, students can't get enough efficiency and give required importance to the practice.

The number of researches related to teaching practice is increasing these days the practice is discussed a lot. In study conducted by Riza and Hamurcu (2000), views practice process of 90 senior students relating to the teaching were tried to be determined with Likert scale formed by researches. According to study results, students have negative opinions for the practice and there are significant different opinions about practice schools.

The study of Ozkilic et al. (2008), Evaluating Teaching Practice According to Views of Teacher Candidates, aimed to receive views of the senior candidate students studying primary school teaching relating to teaching practice. 146 teacher candidates were interviewed. The candidates evaluated themselves as qualified in many education fields. Accordingly, it was determined that the rate of unsuccessful teacher candidates found by practice teachers and instructors was highly low. It was also determined that the teacher candidates found themselves inadequate in dealing with individual differences and using mother tongue effectively.

Whether the feedback was given in teaching practice or how the feedback was given was aimed to be determined in Paker's study (2008). A questionnaire with open-ended questions was given to 80 teacher candidates attending the practice. Also, data was collected through structured interview applied to 25 candidates chosen randomly. It was yielded that the candidates didn't get enough feedback about presenting and planning the lesson they observed.

The teaching practice evaluations and experiences of the primary school mathematics teacher candidates were aimed to be determined in the study of Eraslan (2009), Views of Primary School Mathematics Teacher Candidates Relating to Teaching Practice, under the faculty-school collaboration program. Opinions of 47 mathematics teacher candidates were recorded and analyzed with qualitative research techniques.

According to the results, mathematics teacher candidates couldn't find enough time for the practice couldn't get feedback about the practices, and associate main mathematics courses with school mathematics. On the other hand, the candidates stated that they utilized pedagogical courses during the practice, they felt like they were the teachers of the class, and they found a chance to know better school/class environment and students.

Curtner-Smith and Sofo (2004) tried to find how the practice courses affected the views of physical education teacher candidates about teaching proficiency. For this purpose, information was collected from 20 teacher candidates implemented to open-ended questionnaires and critical incident technique. According to the results, school practice courses significantly affected the views of teacher candidates about teaching profession.

Teaching practice is seen as an important course for teaching skills. Views of the faculty of education undergraduate students in our country relating to this course have been presented by different researchers at various times. In this context, determining the perceptions of the teacher candidates, taking the courses in the field of pedagogical formation program, relating to teaching practice, and determining the problems about this issue and suggestions for solutions are main problems of this study.

Aim

The aim of this research is to determine the perceptions of the teacher candidates about teaching practice in the field of pedagogical formation program and the problems and suggestions of solution about this issue.

\section{Methodology}

In this part, there are instructions about model of the research, study group, data collecting tools, and data analysis. 


\section{Model of the Research}

This research was conducted in accordance with qualitative research process. Qualitative research uses the research qualitative data collecting methods such as observation, interview and document review, and follows a process which puts forward perception and events in realistic and integrative way in their natural environment (Yildirim and Simsek, 2008).

Open-ended question technique was used in order to present views of the teacher candidates in detail. Thus, it was aimed to examine the cases in flexible and unrestricted manner, and directly capture the perceptions of teacher candidates about their experiences, thoughts, and emotions (Yildirim and Simsek, 2008). Participants were asked to answer the questions as they did in interviews. However, these answers were given written, not verbal (Creswell, 2005).

\section{Study Group}

The study group consists of 26 teacher candidates who agreed voluntarily respond to the questions in questionnaire among the teacher candidates attending to teaching practice within the Pedagogical Formation Education Program of Gaziosmanpasa University during the 2015-2016 academic year spring semester. 35 questionnaires were given to teacher candidates, but 9 questionnaires were excluded from analysis due to various missing information. Therefore, 26 teacher candidates 'questionnaires were evaluated in field of the study. Convenience sampling method one of the sampling methods used in qualitative research techniques was used in the study. This method brought speed, easy implementation, and economy.

Table 1.Age Distribution of the Teacher Candidates Attending Teaching Practice within Pedagogical Formation Program

\begin{tabular}{ll}
\hline Age & Frequency (f) \\
\hline $22-25$ & 12 \\
$26-30$ & 9 \\
$31-35$ & 2 \\
$36-41$ & 4 \\
Total & 26 \\
\hline
\end{tabular}

As shown in Table 1 above, 12 of the teacher candidates are in the 22-25 age range, 9 are in the 26-30 age range, 2 are in the 31-35 age range and 4 are 36-41 age range among the participants, attending teaching practice within the pedagogical formation program.

Table 2. Gender Distribution of Teacher Candidates Attending Pedagogical Formation Program

\begin{tabular}{ll}
\hline Gender & Frequency(f) \\
\hline Woman & 21 \\
Man & 5 \\
Total & 26 \\
\hline
\end{tabular}

As seen in the Table 2 above, 21 of the teacher candidates are women and 5 are men among the teacher candidates attending teaching practice within pedagogical formation program.

\section{Data Collecting Tool}

The research data were collected by a questionnaire containing six open-ended questions. Related body of literature was primarily considered during the preparation process of the questionnaire. 5 specialists (two academic members in Department of Curriculum and Instruction, 3 in Department of Educational Administration, Supervision, Planning and Economy) were consulted in order to prove the validity of the questionnaire. After pre-test was conducted with pedagogical formation student at different times, except 3 research participants and in accordance with specialists' opinions, questionnaire with open-ended questions was put into a final form. It was observed that there wasn't $t$ difficulty in understanding and responding to the questions in the questionnaire after the pre-test. This step was followed by practice. Questionnaires were given to the teacher candidates and they were asked to fill out the form when they were most appropriate. Six open-ended questions were addressed to 26 volunteer teacher candidates, to determine the perceptions of the teacher candidates attending to teaching practice within the pedagogical formation program. A questionnaire including these open-ended questions was formed and it was provided that participants wrote their opinions on the form in line with these questions and conveyed the forms to researchers. Questions used to determine opinions of the teacher candidates attending to teacher practice are as follows: 1) What kind of problems have you encountered in teaching practice? How did you solve them? 2) What did teaching practice contribute to you? Explain in detail. 3) How did teaching practice meet your expectations from these practices? 4) How do you evaluate 
the duration you attended to the practice? 5) How should teaching practice be and what should it include? 6) What should faculty academic members and practice teacher in practice school do in terms of teaching practice?

Data Analysis:

Descriptive analysis technique, one of the qualitative data analysis techniques, was used for data analysis. In descriptive analysis, data are classified, summarized and interpreted according to pre-determined themes (Yildirim and Simsek, 2008: 224). Reliability was tried to be increased by quoting teachers' opinions in reporting the data. Participants were coded as practice teacher candidates PTC1, PTC2... PTC25, PTC26. The data collected by 26 formation teacher candidates were resolved by the researchers and transformed into data set in computer environment. Descriptive analysis was carried out according to four stages: forming a framework for descriptive analysis, processing of data according to thematic framework, identification of the findings and interpretation of findings. In this type of analysis, data are presented by directly quoting the views of the persons whose opinions were asked depending on the original forms of the data. According to this, a descriptive analysis is made based on the words, expressions, the language used, the structure and characteristics of the dialogues, the symbolic expressions and analogies in data analysis (Kumbetoglu, 2005). In the research, participants' statements were presented directly, without any correction.

\section{Findings / Results}

In this section, descriptive analysis results, regarding open-ended questions, of 26 teacher candidates attending to teaching practice within pedagogical formation program presented with findings and comments under the codes: problems encountered in teaching practice and solutions, contributions of the teaching practice to the teacher candidates, meeting the expectations of the teaching practice, the duration of application determined for the teaching application, how and what the teaching application should be and what it should include, academic members in faculty and practice teacher in practice school in terms of teaching practice.

Problems Encountered in Teaching Practice and the Solutions

All participants stated that they had various difficulties in teaching practice. Participants often find short-dated and temporary solutions to their problems that they have encountered during the teaching practice. Examples of participants' statements are as follows:

PTC1: “When I arrived at the school, the lesson had already started. I didn't want to interrupt the lesson. When we asked about the school and lessons, the teachers didn't want to talk much. They were uninterested."

PTC4: "Having lunch during the breaks is a problem. And the third one is that it is hard to focus on teaching practice because of undergraduate education, pedagogical formation education, and KPSS."

PTC6: "The course plan that we have is inconsistent with the practiced plan. (the problems arising from the student or educator.). We found the solution in usage of technology and communication between the group representative and the educator."

PTC7: “... Extra preparations for the presentation wasted most of the time as I saw and experienced. This made the lessons a little ordinary. We never were able to solve this problem because we never discussed it. We present an alternative option to the teacher, but we saw it didn't make much sense. We never made it an issue."

PTC9: I had problems at the beginning of the practice as I'm an undergraduate student and it is hard to focus on only the practice. I could ask for a help from my undergraduate teachers to effectively attend the practice."

PTC10: "I had difficulty while coming from another city. When I had to leave early or I was late, I talked to my teachers. They helped me to complete the practice with extra hours."

PTC12: "I was very excited when I first went to practice. I didn't have an experience before. Afterwards, I got rid of the excitement by teaching and attending the practice. Initially, a few students made an attempt to disrupt the lesson. But later I showed that I wasn't too soft. They weren't able to make such an attempt again."

PTC13: "Since I am working, it is very difficult to come to the practice. The course I attended (health care administration) prevented me actively attending the course. It was not related to my profession; I didn't have enough knowledge about the course and couldn't find time find time to prepare. The program was tight, and the students were accustomed to the teacher, the pace, the method. Moreover, different students were teaching each course. All these prevented us from communicating effectively with the students ..."

PTC15:"I had a lack of communication with my group. Our consultant, Hulya, tried to bind us, but the friends didn't approach moderately. There was polarization."

PTC16:"In my teaching practice, I didn't have any problems on my own behalf. We were good with school management, practice educator and students. As working people, we were a little nervous about setting up the day when we first started 
to the practice. We solved the problem by talking to the practice teacher and we adjusted the appropriate internship days for all of us."

PTC19: "Students were making noises. There was some technical problem with the smart board"

PTC21: "The only problem I had in teaching practice was that I had lessons in the faculty on the practice day and my teachers were very strict about attendance. To solve this problem, I continued spending my absence each week, two hours of my own lesson and two hours of teaching practice."

PTC22: "Pedagogical formation education is an intensive program that cannot educate student as much as they need because the time that the education is compressed is very stressful. The fact that the student is in the last year, he/she takes various exams and at the same time he/s is having the pedagogical training causes psychological pressure for the student. This brings failure."

PTC23:"I didn't think that teaching courses would force me hard at first. One of the reasons why I was forced was to having difficulties while expressing myself. I realized I turned my eyes away as I could not look into the students' eyes. I didn't encounter any problem with the attitude of the students towards me. I think, it has something to do with the school I went to. "

PTC24: "Unfortunately, the current problem hasn't been solved. And the problem is formality formation program it's all about wasting people's time. I believe that there is a commercial purpose behind this program. If one day a student having financial difficulties takes the program (formation) appropriately I may feel okay about the program. On the contrary, it will be all in vain; it cannot go beyond a formality program!"

PTC26: "Transportation, exhaustion, intense working and education program... We came and left by our own cars; we got tired and were patient."

\section{Contributions of the Teaching Practice to Teacher Candidates}

Many of the participants stated that the teaching practice contributed a lot to them. Participants stated that they learned about teaching, speaking to the classes, getting to know the students, communicating with the students, classroom management, drawing attention etc. Examples of statements are as follows:

PTC1: "I gained experience about speaking in front of the class, controlling the class, getting involved the students to the lessons."

PTC2: "I can say that I learned a lot about teaching. Additionally, pedagogical courses brought a lot to me."

PTC3: "Being together with the students gave me happiness. For me, the best part of the formation program was the internship. Seeing the environment of the teachers and spending time with the students made me say that "Gladly, I'm taking the formation program." I observed the education system better in teaching practice."

PTC5: "I think, I gained experience about communication with the students, planning the lesson and using teaching methods."

PTC7: "We made presentation in front of our friends in both undergraduate and formation courses. We took some advantages by experiences before the teaching practice. Teaching as a teacher candidate in high school and in front of the class supposing they are our students is both exciting and energetic. The internship took place for weeks in the same school and with the same students created a great relationship between students and us. I realized that I can empathize with the students when thinking that we are still students in formation program."

PTC8: "Teaching practice showed me how teaching profession is blessed, pleasant and satisfactory. I can say that I've found how to transfer in the best way the information we know."

PTC9: "I had worries about speaking to a class and continuing the flow of narration, and I noticed that it was not that big problem with my observations over time. Practice teachers helped with speaking to the class, classroom management, getting attention to the lesson. I observed the school and the course environment as a teacher candidate in terms of education. This was effective on my self-confidence."

PTC10: "I learned how to speak to the students and communicate. I looked for and answer to the question of what I should do to make the lesson active. I found a way by using the methods we learned in the courses."

PTC11:"Everyone has lectured to his/her brother or neighbor, even his/her elders, including me. I learned during the course what is to teach and learn while teaching. I learned how to win students who are out of standards such as lazy students, bad students and sleeping students."

PTC12: "It was an experience for me. Attending to the practice was never a burden to me. I learned how to communicate with the children." 
PTC13: "Teaching in real environment and communicating with the students we speak to is helped me to realize my mistakes and deficiencies."

PTC17: "I realized that there could be really interesting students. It made me see the teachers who can understand their students by looking at the students' eyes or attitudes."

PTC19: "I learned about the teaching profession through my experiences. I had the opportunity to practice the appropriate attitudes and behaviors in the classroom. I had the opportunity to implement the plan I prepared to teach the lesson."

PTC21: “... I experienced the wish for learning, communication, and sharing with 30 pairs of eyes looking me. Of course, midwifery is a profession that gives all quite different pleasures, but teaching has provided me an environment that I can personally meet with young people"

PTC23: "The teaching practice gives me the ability to understand student psychology better. Moreover, I clearly understand the inadequacy of teaching system in our country, and clearly see that there is no relation between world's education system and ours. I don't think students know why they are at school. I don't think they're told."

PTC24: "It strengthened the self-confidence I have."

One of the participators (PTC4) stated that teaching practice didn't bring much to the candidates.

PTC25: "In fact, I don't think it brought much thing. Theoretically, I don't think I've become that good. It may contribute in any case, but I think it is less. Maybe if I hadn't had this training, I would have given the same training".

Another participant (PTC1) expressed that the teaching practice course should be extended a period of time. Also, the participant stated that the practice teacher and practice academics should pay more attention to the candidates, that is, they should pay attention to the lesson. The participant's opinion about the situation is:

PTC22: "Teaching practice should be for an extended period of time. I don't think that the teacher candidates were informed sufficiently before the practice and practice teachers and practice academics didn't pay attention during the practice."

The State of Teaching Practice to Meet the Expectations from These Practices

Participants expressed that the teaching practice met expectations from this practice. However, when the data were analyzed, it was seen that the participants didn't enough information about the application itself; therefore, the expectations from this practice were low. So, we can say that low expectations and inadequate knowledge about the practice made easier to meet expectations more easily and quickly. Examples of the opinions are as follows:

PTC1: "I thought about how I could control the class by myself or how teaching felt; I experienced these."

PTC2: "It met my expectations from courses and performance in internship, but the duration of the lessons was too long. Also, the program in academic calendar quite forced me."

PTC3: "It was exciting and exhausting. It felt good to be in internship. The school members and students were very respectful. Actually, it was over my expectations. I'm working, so I thought the school and internship days couldn't be arranged. My advisor helped me a lot about the situation."

PTC5: "Before starting to the practice... I thought the teaching practice should be more than the theory courses. As the practice place is a classroom, implementing the learned knowledge and observing the results could be better. I implemented the knowledge I learned in the lessons as good as I can. My expectation was to show the students that the history wasn't really a story and it could be fun. I think I was successful partially. But as I said; partially."

PTC6: "I was planning to attend the lesson and end it as a listener. However, it was beyond my expectations to prepare for the subject, chosen by our teacher, and teach it, take the exams, teach in classes without a teacher, and talk to the students."

PTC7: "I can say that I gained a lot. Me and the friends shared the topics of the child health lesson and taught the topics. We memorized what is written in the course book, which subjects stand on which page and what follows them. Frequent plan changes affected the situation. Our teacher gave us opportunity for activities, techniques, and games. This made the lesson productive."

PTC9: "My concerns before the practice got lower during the practice, and teaching was effective for me since it made me review my knowledge and show me what I should learn."

UOA10: "If it was possible for our advisor would come to class, observe us, and give positive-negative feedbacks, it would have been very good in terms of our development. Our advisor' attributions were very important for me because the teachers in vocational school didn't use effective teaching techniques. My expectations were met as possible." 
PTC11: "I was planning to attend the lesson and end it as a listener. However, it was beyond my expectations to prepare for the subject, chosen by our practice teacher, and teach it, take the exams, teach in classes without a teacher, and talk to the students."

PTC13: "At the end of the practice, I expected to find an answer to the question; what I can do to control the class. But to find an answer to this question was harder than I expected."

PTC16: "I panicked a little when I learned that we would teach to the 12.grade. However, the intimacy and interest of the students removed the problem. Shortly, it was a pleasure to be a part of the teaching practice."

PTC18: "Before starting to the practice... I thought the teaching practice should be more than the theory courses. As the practice place is a classroom, implementing the learned knowledge and observing the results could be better. I implemented the knowledge I learned in the lessons as good as I can. My expectation was to show the students that the history wasn't really a story and it could be fun. I think I was successful partially. But as I said; partially."

PTC19: "The practice was positive about meeting my expectation; it helped me to feel the emotion of being a teacher."

PTC21: "I met my expectation partially. If I hadn't had my own lessons, I would have attended to the practice and taught more lessons."

PTC22: "It changed my point of view. Still, I don't think it is enough and my bad is full."

PTC23: "It was extremely good. But as I said before, it didn't serve for the purpose. It was all formality. It didn't meet the expectations, and it won't meet the expectations if it's on a short period of time."

PTC24: "I found what I expected because I didn't know many things to expect. It was enough for this short period."

PTC26: "Teaching profession requires patient and discipline, not many people can do."

Duration of the Teaching Practice

Significant amount of the participants stated that determined duration for the teaching practice was enough. Examples of opinions about the situation are as follows:

PTC1: "Duration was enough, but there could be more teaching because every teaching experience gave us confidence."

PTC2: “...I went to lessons regularly and I found chance to observe the teacher. The feedbacks given by the teacher after every teaching contributed me a lot."

PTC3: “...It was enough for observing the school and the students.”

PTC5: “...More time should be spent for the practice but since the formation program is limited, it isn't possible.”

PTC6: "At the end of the practice, I could chat with the students, be counselor for them, and could guide them partly. This is a kind of communication which can happen thanks to trust and spending enough time. As a result, the practice duration was enough."

PTC7: "I attended to the practice for 10 weeks. If we consider the some part of the formation program, I find the duration enough. YGS (higher education examination) on the first 2 weeks of the practice causes the students don't come to the school. With the inexperience of the first week, it is difficult to have the extra program at school, so you may have to be with two students without teaching them. For this reason, an extra program can be formed in case the first two weeks overlaps with the examination for the student group in the last year. "

PTC8: "The period given for the internship was enough. I evaluate the situation according tothe time I spent for teaching the subjects."

PTC9:"Observation and implementation are sufficient as long as they were spent actively. When the required actions are done, the duration is appropriate."

PTC10: "From the moment the formation program started, it would be better to attend to the internship. We would have had more time to follow up to the students' behaviors and attitudes."

PTC11: "At the end of the practice, I could chat with the students, could be counselor for them, and could guide them partly. This is a kind of communication which can happen thanks to trust and spending enough time. As a result, the practice duration was enough."

PTC13: "I think the duration was not enough for realizing our deficiencies and renewing ourselves. But the short time made me happy because I had difficulties attending to the practice."

PTC14: "I think the attendance time was enough, because after some time we start to repeat ourselves." 
PTC16: "I don't think the attendance time wasn't enough. If teaching practice is implementing and improving our knowledge and skills we gained, I can say that we are in the implementation phase. There was not enough time for development."

PTC17: "14 weeks are not less for me. I think it will not be enough for the teacher candidate for any length of time because there is no end to learning in teaching. The teaching is one of the professions that no one can say "I'm done."

PTC19: "The time I spent on practice was enough to warm up the teaching profession. Both the teaching and the observing times were sufficient in terms of comprehension of the profession."

PTC20: "I think, the duration was ideal and enough. We were given time to make observations apart from the practice. Targets were reached at the desired level."

PTC21: "The time I spent was enough for me because I completed topics I needed to teach. I was supervisor at three examinations, and I collaborated with my advisor to prepare the questions of two exams. I think the important thing wasn't the time, but how I spent it and I think I was productive."

Some of the participants stated that the training for teaching practice was not sufficient. While all the female participants found the time for teaching practice, all male participants find this period inadequate. The views on this subject are as follows;

PTC4: "Of course, it was not enough. The practice shouldn't be limited with several months; it should be extended over a period."

PTC12: "It is not the hardness of a drop that pierces a stone, its continuity and reinforcement as you know. Consequently, if there is more time and it is extended over appropriate period, it will be more successful in my opinion."

PTC18: "It is certainly not enough. We attended the practice six or seven times, and we can't be perfect in this short period of time."

PTC25: "Not enough. It should continue after assignation."

PTC26: "I've seen that academic members in faculty of education are not patient to the students attending the formation program; moreover, they marginalize the students. This situation becomes the most popular topic that formation program students talk in breaks."

\section{How the Teaching Practice Should Be and What It Should Include}

Participants stated various opinions about how the teaching practice should be and what it should include. Examples of opinions about the situation are as follows:

PTC1: "Teacher should be more interested; they shouldn't underestimate the trainees. It should include more lesson teaching."

PTC2: "I think it would be better to attend the practice once in a week. It should be consecutively, so that the students get used to the teachers easily and the teacher get used to the class."

PTC3: "Actually, we can observe much more if we attend the practice twice a week, not once a week... I think it would be better to have more than one advisor with whom we can work alternately."

PTC4: "Someone should follow it in all terms. Every day, detailed explanations should be made. Moreover, a committee should listen."

PTC6: "For me, it was qualified education program."

PTC7: "Plan and program should be formed again. We should be informed about which teacher will be at which lesson, on which grade, at which hours. If it is possible, sharing the topics should be done in advance. More subjects should be taught in practice. Observation should be in the first and the last week. In first week, mistakes should be corrected, and deficiencies should be overcome. At last, a detailed observation can be done."

PTC8: "I don't think there is wrong with the teaching practice."

PTC9: "Students should teach lesson at least two times. Feedbacks should be given by academic member in an appropriate communication environment."

PTC10: "It would be better if fewer students work with the teacher, not 5-6 trainees. The practice should be considered as a whole. Gathering with the students in breaks can be arranged."

PTC11: "For me, it was a qualified education program." 
PTC12: "Faculty teachers should observe the practice, at first, and give feedback. We should spend time alone with the class towards the end of the practice. When there is a teacher in the classroom and we realize we are being observed, it may be hard to perform."

PTC13: "It would be good to know the teaching practice program, and the lessons when the formation program started for preparing the subjects and arranging the hours we will attend the practice."

PTC14: "It would be useful for a teacher candidate to teach the lesson for a week, not under the observation of a teacher, and at the end the teacher observe the teacher candidate. It may be more effective for both the students and trainee student."

PTC15: "Students should be educated by understanding, knowledgeable, cheerful, and positive teacher. She/he should guide and be supportive. Also, that person should help students to solve their problems."

PTC17: "The aim is to make the teacher candidate more active and to ensure the students actively participate in the lesson. I think the practice is also a tool for it. Perhaps, the practice process should be a little longer. Because when we are get used to it, the teaching practice is over. "

PTC18: "My department is the history and most high school students don't like it. For example, in places such as Tokat, history can be explained by using the local history. It would be both more instructive and more memorable. Trips to historical sites can also be organized"

PTC19: "The practice would have been more useful if it had been in the regions where we resided. The duration for teaching the lesson should be kept longer rather than duration for observation."

PTC20: "The current system is good for me; I don't think there is need for an extra plan. The time for both observation and practice is given."

PTC21: "It should be more systematic. For example, at the beginning of the period it should be clear who will teach which subject and on which day. The school must also set up its own system, for example, if the school is three weeks behind the plan, it should arrange for additional studies or courses so that there won't be problems."

PTC23: "Teacher candidates who will attend to the teaching practice should have knowledge firstly about how to manage the class, how to communicate with the students. These should be learned thoroughly and then the candidate should attend the practice."

PTC25: "Apart from a few things we have seen in lessons, I can't say that I have done everything properly, so I believe it would be better if we can do the practices we observe in class."

PTC26: "It should continue after the assignation, at least for a semester. After gaining enough experience, the teacher starts to teach."

What Should Responsible Faculty Academic Member and Practice Teacher in the Practice School Do within Teaching Practice

Participants stated various opinions about what faculty academic member and practice teacher should do. Examples of opinions about the situation are as follows:

PTC2: "I think that teaching practice should not depend on a single teacher. I believe it would be very useful for us to enter many different courses during the internship period."

PTC3: "I feel lucky about it. Both of the teachers were very understanding. When I had a problem and talked to them, they were always good to me."

PTC4: "I really got the benefit from both my teachers. They helped me; I often spend their time. They're interested to me. It was sufficient for me. All in all, they were helpless about the situation."

PTC5: "The teacher in school should observe the student and share the deficiencies with the student outside of the class."

PTC6: "Under the collaboration of the academic member and counselor teacher, students needing the support can be mentored by teacher candidates."

PTC7: "The evaluation of the candidate must take place in at least two stages. Subjects should be arranged with practice teacher in advance. School practice teacher or a school administrator can give school orientation training to the internship groups in the first week. The technical room and the materials in it should be well known by the school teachers and it must be presented to us."

PTC8: "I am very happy with the faculty member in the faculty and the practice teachers in the practice school. I don't see a situation they need to make any changes in their behavior." 
PTC9: "Academic member can observe the students' teaching in group arrangements and give feedbacks. The teacher in the school can be a guider about the practice."

PTC10: "If teachers in the practice school use actively the techniques about attracting the students' attention and evaluation of the learner, it increases the chances observing these practices. When we implement ourselves, we can have a chance to determine how to use alternative ways and what to include or exclude. The teacher should come and observe our teaching, then give feedbacks as our faculty academic member does."

PTC11: "Under the collaboration of the academic member and practice teacher, students needing the support can be mentored by teacher candidates."

PTC12: "The faculty academic member should talk about the things we should do when we go to the practice school because we will encounter with an environment we don't know. We should know what to do more or less. Later, practice teacher in practice school should give information about the class's atmosphere."

PTC13: "I think it will be useful for us, facing with the teaching for the first time, if the practice teacher in the school hold a short meeting after each lesson, and exchange opinions with the students while preparing the lesson"

PTC16: "Both the practice teacher in school and academic member should observe the teacher candidate and give feedbacks to show the deficiencies and improve."

PTC17: "I had a great teaching practice. Both academic member and the practice teacher in practice school helped me a lot."

PTC18: "The teacher in school should observe the student and share the deficiencies with the student outside of the class."

PTC19: "Should present the knowledge and experiences to the teacher candidate. Information should be given about our behaviors and attitudes in class, and lesson plan. They should teach us our deficiencies and mistakes."

PTC20: "Faculty academic member shouldn't go to the practice school every week because it increases the rate of excitement. She/he should go to the school at particular times."

PTC21: “Academic member shouldn't be given too much workload. Fortunately, we were with an understanding teacher, but I wanted my supervisor to observe me personally. But if the board is giving the responsibilities of undergraduate, doctoral and master's degree students, it should predict that not all of them will progress in the same way. "

PTC23: "I don't think I was informed sufficiently. I think that there is a communication problem among the teacher candidate, the faculty member and the practice teacher. I also want you to know that teacher candidates are not treated as they should be."

PTC25: "Our teacher did what they could do in short period of time. I have no doubt that if the time had been a bit longer, they would have shared their experience and knowledge."

\section{Discussion and Conclusion}

Teaching practice has been a debate for a long time. Teaching practice is dealt with in many different dimensions in these discussions. In this study, all participants stated that they experienced various problems during the teaching practice. Participants often find short-dated and temporary solutions that they have developed to overcome the problems they experience in the teaching practice. This findings similar with the study of Isikoglu et al. (2007), conducted to determine the problems encountered during teaching practice in primary school, which points out that teacher candidates have difficulty to show their presence in class, and to professionally communicate with practice teachers and other staff. Many of the participants stated that teaching practice contributes them a lot. What they mean by saying a lot is teaching lesson, speaking to the class, getting to know the students, communicating with the students, class management, attracting attention etc. This findings have similarity with Guven's study (2004), A Qualitative Research on a Teaching Practice Experiences of Teacher Candidates in Social Sciences Field whose aim is to determine field experiences and thoughts of students in School Practice lesson and to find solutions for the problems, which shows that teacher candidates find teaching practice useful, are ready for the basic teaching, and implement the techniques of controlling the students, and Eraslan's study, Views of Primary School Mathematics Teacher Candidates about Teaching Practice, which shows that teacher candidates use the knowledge they learn in profession lessons in teaching practice, they feel as if they were the real teacher of the class, and find a chance to know better school/class environment and students.

Most of the participants state that teaching practice meets the expectations, which means they find the practice useful. This result is consistent with the studies conducted in similar fields ( Curtner-Smith and Sofo, 2004; Guven, 2004; Ozkilic, Bilgin, Kartal, 2008; Becit, Kurt, Kabakci, 2009;). However, when the data is analyzed again, it can be see that participant don't have enough knowledge about the practice, so they have low expectations. Therefore, the fact that participants have low expectations and don't have enough knowledge about the practice shows that relevant practice meets expectations easily and quickly. 
Participants also stated that determined duration for practice is enough. How this duration is spent is more important than the quantity of the practice.

Participants have various views about how the practice should be and what it should include. Participants expect that academic member and practice teacher should be more involved with them, the lessons should be planned and lesson programs should be functioning, and also they want to use the knowledge they learn in the faculty in the practice etc. These findings match with the Ozkilic, Bilgin, and Kartal's study (2008), Evaluation of the Views of Teacher Candidates about Teaching Practice, presenting 146 teacher candidates' views. At the same time, the study matches with the Gokce and Demirhan's study (2005) presenting views of 80 practice teachers and 341 teacher candidates. Teacher candidates participated in Gokce and Demirhan's study stated that practice teachers should make informing meetings once a week, academic member should corporate with practice teacher and the interaction should be improved, school administrators and practice teachers were careless towards them.

It can be understood that participants were happy with the practice academic member and practice teacher as they were unhappy with them. This situation is significant for determining which teacher candidate will work with which academic member or practice teacher. If the candidate works with an academic member or practice teacher who takes his/her work seriously, positive thoughts will be developed and the practice becomes productive; on the other hand, if the candidate works with an academic or a practice teacher who doesn't take her/his work seriously, negative thoughts will be developed and the practice becomes nonproductive. This result matches with Paker's study results, Problems Teacher Candidates Encounter Related with Guidance of Academic Member or Practice Teacher in Teaching Practice.

According to the results of this study, teaching practice should be maintained seriously, and the number of students, faculty academic member and practice teacher in practice school are responsible for, should be less. Teacher candidates attending to the practice should gain more experience by planned teaching practice program.

\section{References}

Altunisik, R., Coskun, R., Yildirim, E., \& Bayraktaroglu, S. (2001). Sosyal Bilimlerde Arastirma Yontemleri-SPSS Uygulamali[Research Methods in Social Sciences-SPSS Applied] Ankara: Sakarya Kitapevi.

Becit, G., Kurt, A.A. \& Kabakci, I. (2009). Bilgisayar ogretmen adaylarinin okul uygulama derslerinin yararlarina iliskin gorusleri [Computer teacher candidates' views on the benefits of school practice courses].Anadolu Universitesi Sosyal Bilimler Dergisi, 9(1), 169-184.

Berg, B. L. (1998). Qualitative Research Methods for the Social Sciences. Boston: Pearson/Allyn \& Bacon.

Creswell, J.W. (2005). Educational Research: Planning, Conducting and Evaluating Quantitative and Qualitative Research (2nd ed.). Upper Saddle River, N.J.: Pearson Merrill Prentice Hall.

Curtner-Smith MD, Sofo, S. (2004). Influence of a Critically Oriented Methods Course And Early Field Experience On Preservice Teachers' Conceptions Of Teaching. Sport Education and Sociaty, 9(1), 115-142. DOI: $10.1080 / 1357332042000175845$.

Esaslan, A. (2009). Ilkogretim matematik ogretmen adaylarinin "ogretmenlik uygulamasi" uzerine gorusleri[opinions of elementary mathematics teacher candidates on "teaching practice"].Necatibey Egitim Fakultesi Elektronik Fen ve Matematik Egitimi Dergisi, 3(1), 207-221.

Gokce, E. and Demirhan, C. (2005). Ogretmen egitiminde yenilikci bir yaklasim mi yoksa geleneksel bir anlayis mi? [an innovative approach or a traditional approach to teacher education?]. Ankara Universitesi Egitim Bilimleri Fakultesi Dergisi 38(2),187-195.

Guven, I. (2004). Sosyal bilgiler alan ogretmen adaylarinin okul uygulamalarina yonelik gorusleri uzerine nitel bir calisma[A qualitative study on the views of social sciences field about school practices].Kuram ve Uygulamada Egitim Bilimleri, 4(2), 273-290.

Harmandar, M., Bayrakceken, S., Kincal, R.Y., Buyukkasap, E., \& Kizilkaya, S. (2000). Kazim Karabekir Egitim Fakultesinde okul deneyimi uygulamasi ve sonuclarinin degerlendirilmesi[Evaluation of school experience application and results at Kazim Karabekir Faculty of Education]. Milli Egitim Dergisi, Sayi:148, 3-6,

Isikoglu, N., Ivrendi, A. ve Sahin, A. (2007). Ogretmenlik uygulamasi surecine ogretmen adaylarinin gozuyle derinlemesine bir bakis[A deeper look at process of teaching practice from teacher candidates' perspectives]. Egitim Arastirmalari Dergisi, 26, 131-142.

Kucukahmet, L. (2007). 2006-2007 Ogretim yilinda uygulanmaya baslanan ogretmen yetistirme lisans programlarinin degerlendirilmesi [Evaluation of teacher training graduate programs that started to be implemented in the academic year]. Turk Egitim Bilimleri Dergisi, 5(2), 203-218. 
Kumbetoglu, B. (2005). Sosyolojide ve Antropolojide Niteliksel Yontem ve Arastirma[Qualitative Method and Research in Sociology and Anthropology]. Istanbul: Baglam Yayincilik.

Oguz, A. (2004). Okul deneyimi dersinin ogretmen adaylari uzerindeki etkileri [Effects of school experience course on teacher candidates]. Dumlupinar Universitesi Sosyal Bilimler Dergisi, 11, 141-162.

Ozkilic, R., Bilgin, A. \& Kartal, H. (2008), Ogretmenlik uygulamasi dersinin ogretmen adaylarinin goruslerine gore degerlendirilmesi [Evaluation of teaching practice course according to the opinions of teacher candidates]. Ilkogretim Online, 7(3), 726-737) [Online]: http://ilkogretim-online.org.tr.

Paker, T. (2008).Ogretmenlik uygulamasinda ogretmen adaylarinin uygulama ogretmeni ve uygulama ogretim elemaninin yonlendirmesiyle ilgili karsilastiklari sorunlar [Problems faced by teacher candidates related with the guidance of application teacher and application in teaching practice]. Pamukkale Universitesi Egitim Fakultesi Dergisi, Sayi: 23, 132-139.

Riza, E.T. \& Hamurcu, H. (2000). Sinif ogretmenligi bolumu ogrencilerinin okul deneyimi ve ogretmenlik uygulamasina yonelik gorusleri [opinions of classroom tutorship division students on school experience and teaching practice]. Pamukkale Universitesi Egitim Fakultesi Dergisi, Sayi: 8, 91-97.

Turnuklu, A. (2000). Egitimbilim arastirmalarinda etkin olarak kullanilabilecek nitel bir arastirma teknigi: gorusme [Qualitative research technique that can be effectively used in pedagogic researches: interview]. Kuram ve Uygulamada Egitim Yonetimi Dergisi, Sayi: 24, 543-559.

Yildirim, A. \& Simsek, H. (2008). Sosyal Bilimlerde Nitel Arastirma Yontemleri [Qualitative Research Methods in Social Sciences]. Ankara: Seckin Yayinlari.

Yuksek Ogretim Kurumu (YOK) (1998) Egitim Fakultesi Ogretmen Yetistirme Lisans Programlari[Faculty of Education Teacher Training Undergraduate Online: http://www.yok.gov.tr/documents/10279/30217/Egitim_fakultesi_ogretmen_yetistirme_lisans_programlari_mart_ 98.pdf/5e166018-b806-48d5-ae13-6afd5dac511c. (Erisim tarihi: 17.06.2107). 